\title{
Climate Change, Adaptation, and Water in the Central Andes
}

\author{
Armando Lamadrid \\ armando.lamadrid@gmail.com
}

\begin{abstract}
Irrigation has been central to the development of societies throughout the history of the Andes, in times of both social and environmental change. In the era of modern anthropogenic climate change, however, narratives of diminishing snow and ice cover-and the precious meltwater that countless irrigation systems depend on-present mostly negative explanations of change without sufficient local detail, both environmental and social. Environment in the Andes, for instance, is by definition a broad spectrum of realities, both arid and moist. Society too is multifaceted across the region. Several studies conducted on Andean irrigation systems past and present provide such muchneeded knowledge on the dynamics of complex socio-environmental change that the "meltdown" glosses over. What emerges from a review of selected research findings from Cotacachi, Ecuador to Elqui, Chile and several cases in-between and across time, is that environment is not the most important driver in times of flux, but also social processes and the (im)balance of power that determines, inevitably, to whom the water flows. With attention to these socially and environmentally contextualizing cases, thus, this paper aims to confront the broad-brushstroke "meltdown" narrative portrayed in the public sphere with the development of a more nuanced, placebased understanding of the dynamic interplay of environment, society and power over space and time to better understand, if not the process of change itself, at least the most important elements to be aware of when describing the socio-ecological impacts of climate change on small-scale irrigators of the Andes.
\end{abstract}

Keywords: Climatic change, adaptation, irrigation, small-scale farming, Andes

\section{Introduction}

Irrigation-based small-scale farming has historically been the most important source of production, sustaining a myriad of cultural groups over thousands of years in the Andes. Andeans are so closely associated with their irrigated agriculture that, as with many other irrigation cultures from around the world, it has become an important part of their culture and identity. Andinidad or lo andino, both broadly 'Andineity', are concepts defining Andean peoples and their indigenous identity as much by their customs, language and religion as with the snow-and-ice-capped mountains, meltwater laden streams, and irrigation canals conveying precious moisture to thirsty crops.

Today, the vast mountain chain of the Andes and other highland regions across the planet are undergoing profound changes as a result of climate change and global warming. The most visible sign of this are the melting glaciers and snow of the high Andean peaks, which have receded-dramatically and completely in some places-since the Little Ice Age (Vuille et al., 2008). The loss of the shimmering glaciers of the Andean landscape, like Chacaltaya glacier in Bolivia and the glaciers flanking Cotacachi volcano in Ecuador, have caused increasing alarm in society as harbingers of a dangerously changing world-foreign from the one Andeans know and depend on today for survival.

Visible symbols of the impacts of climate change, the receding glaciers and snow tell a story beyond the marked disappearance of the color white from the mountain tops. This story has to do with the changes to the color blue-the life-giving water supporting the millionsof inhabitants of the Andean region. Holding 99\% of the world's tropical glaciers (Kaser, 1999), the Central Andes are hydrologically like no other mountain range in the 
tropics. Glacier melt constitutes an important supply of water to which civilizations in the area have adapted to over millennia. Glacier and snowmelt are especially important for basins draining into the Pacific Ocean, supplying up to $30 \%$ of the annual flow of some streams (Mark et al., 2005, Mark and Seltzer, 2003). So as the snow and ice disappears in our warming world, so too will the water flowing through streams and rivers originating in the Andes during dry periods.

This situation, although of general concern to the people of the Andes, is especially problematic for smallholder farmers in the mountains dependent on melt-water for irrigation. These peasants, or campesinos will suffer most not only due to the fact that the amount of water they depend on in the dry season will diminish, but also that they will come into increasing conflict over the precious resource with much more powerful actors with interests on national and international scales (i.e. urban centers, industrial mining \& agricultural development, etc.). Since most of these small holder agriculturalists are largely outside of the influence of the state, they are furthermore left to their own devices when it comes to appropriating water for agriculture. Water scarcity due to climate change or depleted glaciers is thus of serious concern. For these and other reasons, the Andes have been described as one of the most vulnerable in the world to climate change.

The narrative of the causal chain of melting snow and ice caused by anthropogenic climate change leading to severe impacts on society, including small-scale irrigation communities on the margins, is used as a call to action for increased adaptation research, climate change reparations, and development action. But in light of the uncertainties surrounding the impacts of climate change and how societal and other pressures will mix with these, this paper asks whether or not this narrative of adaptation is actually constructive for smallscale irrigation societies in the Andes. For instance, many difficulties arise when applying this narrative structure to certain Andean cases, such as urban water resources planning, since adaptation in this context is normative, favoring supply-side technocratic adaptation over demand-side adaptation.

Since cultural responses to climatic and environmental change are more varied than the modern discourses of adaptation in the literature reflect, this paper will look at historical and contemporary cases of how Andean societies dependent on irrigation have adapted to changes in climate, and what their vulnerabilities to these and future change are. This will hopefully inject the Andean 'meltdown' narrative-similar in other ice-covered mountain ranges of the world - with local contexts and histories in order to better conceive of the complex relationship of Andeans to their environment and their vulnerabilities in the context of climate change.

\section{Climate Change in Past Andean Societies}

Irrigated agriculture has a very long history in the tropical Andes region, and contributed to the independent rise of complex states- "ecologically invasive social orders" (Scarborough 2003) - in this major world region. For the Andean civilizations that mastered irrigation technology, this became the economic adaptation that allowed them to expand into the hydrologically variable environments of the Andes, marked by a seasonal water deficit, or dry season. Thus for millennia, Andean cultures have depended on the variable mountain sources of water, and because of local seasonality became masters of water control over time. The vast area of terraces sculpted onto remote mountain slopes across the region 
bear testament to this evolution. Thus, the notion of 'irrigation society' is an appropriate way to describe the hydrologically sophisticated Andean cultures across space and time.

The analysis of past climate changes on society is a helpful exercise for studying how complex societal and environmental factors mix to produce a historical outcome. Although historical vulnerabilities to stresses may be a world apart from the context of present climate changes, we can nonetheless hope to gain a better understanding of how societies in a similar ecological setting responded to changes, both human and environmentally-induced in the Andes. In this wider context, we can hope to understand some of the dynamics of change in the Andes more broadly with implications for modern societies. The cases chosen for discussion of past changes in the Andean context are the collapse of the Tiwanaku and Wari cultures of the southern Peruvian and northern Bolivian Andes in the $11^{\text {th }}$ century $\mathrm{AD}$, and the rise of the Inca Empire culminating in the $15^{\text {th }}$ century AD.

The study by Williams (2002), of the archaeology of the Moquegua Valley in southern Peru is an analysis of the complex interplay between social and environmental vulnerabilities that caused the collapse of two peripheral provinces of the Tiwanaku and Wari cultures in the $10^{\text {th }}$ and $11^{\text {th }}$ centuries $\mathrm{AD}$, respectively. In both cases, these societies utilized irrigation canals for agricultural production. In the Tiwanaku colony, evidence suggests that "agricultural colonies of Moquegua provided the state with exotic staple products not obtainable in the altiplano heartland" (Williams 2002) of the Lake Titicaca region. It is worth noting that the Moquegua valley is much lower ( 1000-1500 masl) than the altiplano region ( 4000 masl), thus would have been a valuable ecological zone for maize production for the Tiwanakustate. The Wari colony expanded into the upper tributaries of the Moquegua watershed around AD 600, coinciding paradoxically with a thirty years' drought. Although Wari canal technology was more advanced than Tiwanaku and the combination of stone masonry terracing allowed them to irrigate 2.5 times the area per volume than Tiwanaku canals, they benefited from closer proximity to highland rains above 3500 maslas well (ibid). For 400 years, the two colonies persisted side by side, in apparent tolerance of each other. However, in instances of drought, Wari utilization of upstream water resources decreased downstream Tiwanaku availability and thus hampered production, causing tensions as may have occurred during a dry period in the $7^{\text {th }}-8^{\text {th }}$ centuries AD. Eventually, the Tiwanaku colony in Moquegua collapsed in the $10^{\text {th }}$ century, and although environmentally induced water shortages have been hypothesized as the reason, the ecological effects of drought are not evident in the Titicaca heartland until the end of the $11^{\text {th }}$ century AD (ibid). Williams, thus hypothesizes that "local factions within the Moquegua Tiwanaku populations were developing, perhaps in response to the high degree of economic interdependence forced on them by the state", and the loss of this prime maize producing region may have aided in the collapse of the central authority (ibid: 372). Additionally, conflict between the Wari and Tiwanaku colonies may have led to the demise of at least one of the Moquegua Tiwanaku sites, and water mismanagement at another site appears to have led to its decrease in production and subsequent abandonment. The Wari colony on this, the only frontier between the Tiwanaku and Wari states, was abandoned not long after the Tiwanaku colony in the Moquegua Valley. This, Williams explains, is nocoincidence:

The events precipitating the local Tiwanaku collapse inevitably affected the politics of Wari control in the drainage. Perhaps with the demise of Tiwanaku state presence, the principal 
reason for the Wari occupation of Moquegua - to contain and interact with the Tiwanaku

frontier - was no longer an issue. (ibid: 372 )

Thus, environmentally induced water shortage does not appear to be a dominant cause in the collapse of these Andean states, even though both were vulnerable to drought. With the lessons drawn from the Wari and Tiwanaku cases, Williams reflects that " $t$ ]he magnitude of a natural hazard cannot be equated with the magnitude of its social impact" (ibid: 372). The social responses are rather the result of "the process of coping with disaster and the inherent vulnerabilities in social systems" (ibid: 372). To summarize, the prime vulnerabilities in Tiwanaku and Wari societies leading to their collapse according to Williams were social unrest and conflict, water mismanagement, and environmental factors such as drought—largely social over environmental causes.

A reason for the disaster-induced collapse theory of the Wari and Tiwanaku cultures stems from the fact that the post collapse period was characterized by a centuries-long drought. But even though the Wari state disappeared,their 'high sierra agrarian technology'mountain-side terracing and irrigation canals-provided a competitive edge for later civilizations, namely the Inca (ibid: 372). The Inca have long been recognized as the group who brought the Wari's technology to pre-eminence, expanding it across the Andean region.

As Chepstow-Lusty et al. (2009) explain, the rapid, prolific rise of the Inca has been attributed mostly to "the adoption of innovative societal strategies, supported by a large labor force and a standing army" (375). However, the question of how to generate sufficient agricultural surpluses to support a growing population and army for military campaigns has not been adequately explained. This, they say, is the result of an expansion of agriculture to higher elevations facilitated by an increase in temperatures in the highlands from AD 1100 beyond the arrival of the Spanish in AD 1532. Warmer temperatures allowed for cultivation at higher altitudes, although the drier conditions necessitated the development of irrigation and terracing. Water, fortunately was in abundant supply at this time due to an increase in glacial melt (ibid). As the authors explain, "[t] he outcome of these strategies was greater long-term food security and the ability to feed large populations... [and a] healthy agricultural surplus supported their economic and politicalpotential, enabling them to subjugate other local independent states and to effectively centralize power in the Cuzco region by ca. AD 1400 (Bauer, 2004)" (ibid: 385).This is important to remember, for climate change may transform the environmental context of a culture in a way that benefits it and increases adaptive capacity. In contrast to Williams' (2002) emphasis on the social processes explaining the Tiwanaku and Wari collapses, this new theory of Inca expansion brings environmental and climate changes back into the explanatory framework of social change in the Andes ${ }^{1}$, but in terms of advantages instead of overwhelming hazards. This highlights the importance of considering opportunities in addition to constraints caused by climatic change for societal development and persistence.

\footnotetext{
1 Although, "by incorporating social elements into the equation, we arrive at much more powerful explanatory devices that do not depict human societies as the recipients of environmentally prescribed collapses, but as active agents in the construction of the environment and in their own development" (Williams 2002: 372), "documenting in detail the environmental backdrop against which the Inca expanded their influence and power enhances our understanding of the social, political and economic challenges that they faced" (Chepstow-Lusty et al. 2009: 376).
} 


\section{Climate Change in Contemporary Andean Society}

There is a growing body of research today on the effects of climate change on the vulnerability and adaptive capacity of Andean peoples, including small-scale farmers. This section will highlight a selection of studies conducted investigating present and projected impacts of climate change on highland water-dependent communities and their associated livelihoods. Geographically, the studies range from northern Ecuador to central Peruand the Bolivian altiplanoto northern Chile.

\subsection{Cotacachi Volcano, Ecuador}

Climate change today is already having a dramatic impact on the landscape of and surrounding Cotacachi volcano in northern Ecuador. The most salient change that has occurred to date is the disappearance of the glacier atop the 4939 meter-high mountain. Rhoades (2008) reports that in addition to the disappearance of the glacier, local inhabitants surrounding the volcano have noted changes in the seasonal rainfall pattern. This general shift is characterized by "increasingly scarce and highly irregular rainfall [causing] confusion over field preparation and planting times" (ibid: 45). Strong winds and declining water availability in springs and streams have also been observed. And interestingly, cotacacheños' perceptions converged with scientific modeling of glacier recession where an initial increase in runoff occurs due to rapid melting, but later drops off with the disappearance of the ice mass. Decreased availability of water in springs and streams seems to be directly related to the loss of the glacier.

Irrigation canals in the vicinity of Cotacachi were built over the centuries to support agriculture on haciendas-large land holdings owned by wealthy individuals and families (ibid). After land reforms in 1963 and 1973 redistributed lands to indigenous peoples previously working on the haciendas, the size of haciendas diminished, however "there was no corresponding water reform" (ibid: 45). Indigenous leaders worked to "pressure government authorities for more equitable access to water" (ibid: 45), which led to a period of canal construction for the benefit of indigenous communities throughout the 1990's. But in spite of the creation of new water systems, sharply rising population and increasing demand for irrigation water for the expansion of agricultural industries, including a boom in floriculture, has put increasing stress on local water resources. This has sparked tensions between stakeholders, such as "when indigenous groups in Imbabura Province of Cotacachi blocked the Pan American highway [demanding] greater access to water" (ibid: 46) in July 2005. And finally, the recently created Cotacachi-Cayapas Ecological Reserve, "this northern Ecuadorian area is attracting larger and larger numbers of tourists" (ibid: 48) creating more livelihood opportunities for locals. With the disappearance of the glacier and the mountain turning black, Rhoades asks, "will the attraction be the same?" (ibid: 48). Thus, the multiple stressors of changing rainfall patterns, decreasing water supplies from Cotacachi Volcano, a growing population, increasing demand for domestic and industrial (including agricultural) purposes, and loss of livelihood opportunities (such as agriculture and tourism due to water scarcity and glacier recession, respectively) are compounding peoples' vulnerability to future stressors, including abrupt climate change.

\subsection{The Callejón de Huaylas}

Many of the problems faced in the Cotacachi region of northern Ecuador are emblematic of the impacts of changes felt widely across the Andes today. Mark et al. (2010) describe 
the impacts of glacier melt on the sub-watersheds of the Río Santa in the Callejón de Huaylas region of the central Peruvian Andes, and vulnerabilities of the people inhabiting them. The Callejón de Huaylas is an extraordinary and singular region in the Andes, boasting the magnificent glacier-covered Cordillera Blanca range, which in itself holds more than $25 \%$ of all tropical glaciers globally (ibid.). This is unique, further considering that the Andes alone comprise 99\% of all of the world's tropical glaciated area (Kaser, 1999). In this study, household livelihood vulnerability was assessed, as it is affected by climate change and glacier recession. The authors found that in the Quilcay and Querococha sub-basins, people were vulnerable to decreasing water supply during the dry season, changing weather patterns negatively affecting crops and livestock, extreme precipitation or freezing events damaging crops, livestock and human health with significant implications for basic food security, and a decrease in tourism due to the recession of a local glacier. These emerging vectors of vulnerability highlight further how glaciers constitute an "integral component of coupled natural-human systems of the tropical Central Andes" (Mark 2010: 803), and how changing downstream hydrology will impact present and future human activity, in addition to changes in weather patterns and events, their frequency and intensity.

Bury et al. (2010) also focus on the changes affecting the Cordillera Blanca, but in Catac community in the Yanamarey sub-watershed of the Río Santavalley specifically. This study identifies the main household and community vulnerabilities resulting also from glacier recession and climate change. Like the previous cases presented, Bury et al. (2010) identify threats to tourism, extreme weather events as key factors affecting households. However they also highlight, as Rhoades (2008) above, the problem of peoples' variable access to water resources. The historical legacy of exploitation and inequality leading to high levels of poverty in the region, they assert, are critical for equity of water rights and access in the Río Santa basin. Households in the study area and across the Callejón de Huaylas must compete with the interests of other actors demanding water in the region, including mining, tourism, and very powerful urban, hydroelectric and export-led agricultural interests in the Callejón de Huaylas and in commercial industrial agricultural lands on the arid coast. These socio-economic factors, which have emerged largely since the 1990's, thus also exert pressures on the small-scale agro-pastoralists of the Callejón de Huaylas which are as important as climate change in the consideration of pressures on peasant livelihoods.

\subsection{Bolivian altiplano}

Valdivia et al. (2010) describe the risks that are plaguing people in the Bolivian altiplanothe high, 4000-plus meter-high plateau stretching from southern Peru through western Bolivia and northern Chile and Argentina. For the case areas studied, major climate and market risks were identified. Hail, floods, drought, frost, changing climate and pests were identified as the environmental risks, and low livestock prices and adult unemployment were found to be the salient market risks affecting people's vulnerability. Although residents of the Bolivian altiplano have managed risks to secure their livelihoods for generations, global change is now threatening the success of these measures. Warming, later onset of the rainy season and more extreme weather is undermining production strategies with weather related risks, and as climate changes, the ability to respond to these risks decreases. The condition of growing environmental stress is exacerbated by the fact that "production strategies that used to buffer against climate variability are being lost because of economic, social and market conditions (Zimmerer 1993)" (Valdivia et al. 2010: 819). These multiple exposures are currently making Bolivians of the altiplano more 
vulnerable to environmental and socio-economic stress, yet as the authors find in their study, adaptive capacity improves with the integration of scientific knowledge into local knowledge systems.

\subsection{Colca Canyon}

In a study by Lamadrid (2008), the local perceptions of climate change were explored in the Colca region of Arequipa province, Peru. The precipitous Colca Canyon is home to a vast number of small-scale irrigation systems, famous for their cultivation of prize crops in a wide range of ecological zones, making the region exceptionally productive and diverse despite its remote location. However, only few steams are fed by perennial snow and icemelt from high Andean peaks, so people are beginning to feel the consequences of decreasing runoff during the dry season. This critical "compensation effect"-where snow and ice runoff feeds streamflow far into the dry season until sufficient atmospheric moisture returns - is the biggest concern of people in Cabanaconde and Tapay villages, also corroborated by multiple studies modeling snow and ice-fed streams under climate change. Thus, the depletion of this important reservoir of water looms for people living along these economically and culturally important streams, threatening their agriculture and also the integrity of their community-managed irrigation systems which have survived since pre-Inca times. However, when climate change is placed as the starting point of Colca people's vulnerability, many other important vectors of change in the area are lost, such as economic out-migration (resulting in a "brain-drain" despite more remittances), and "rationalization" of the local water systems due to increased market proximity and access to a major canal project (leading to a loss of the traditional irrigation management institution). Thus the complex social changes occurring and their cultural impacts are also changing the face of irrigation culture in the Colca region, suggesting that simple climate change projections alone cannot give a full picture of the systems vulnerability or the people's ability to adapt in the future. This is supported concretely by people's concern with both social and environmental drivers of change (ibid).

\subsection{Elqui Valley}

Finally, Young et al. (2010) present the current and future vulnerabilities of a snow and icemelt irrigation dependent community, Diaguitas, in northern Chile's Elqui River valley on the arid western flank of the central Andes. Environmentally, the Elqui valley is most exposed to El Niño Southern Oscillation (ENSO) precipitation cycles, careening between wet (El Niño) periods which cause landslides, and dry (La Niña) periods marked by severe droughts. Changes in the political economy of Chile since the 1970's resulted in a rise of irrigation dependent agribusiness (responsible for $85 \%$ of consumptive water use in Chile), and the country's market-oriented approach to allocate use of scare water resources laid out by the 1981 Water Code are two drivers behind the socio-economic exposures of Diaguitas $^{2}$.As identified locally, Diaguitas is vulnerable to debris-flows and flooding, drought, irrigation water shortages, access to potable water and socio-economic exposure sensitivities. The future vulnerabilities identified are increasingly frequent and intense El Niño cycles, debris-flows (affected by an increase in ENSO activity), decreasing rainfall and prolonged droughts projected to result from climate change, temperature increases affecting snow and ice feeding the Elqui River, and a decrease in summer river discharge in the long term after an initial augmentation of flow from elevated melting.

2 A similar clause is present in the 2009 Peruvian Law of Hydraulic Resources (Ley de RecursosHídricos), seemingly elevating private investment related to water use as a 'juridical principle' (Borg-Rasmussen 2010). 
This selection of contemporary vulnerability research in the Andes shows that land-based societies are at risk to changes in the local hydrological and climatic regimes. Droughts, flooding, extreme weather and rising temperatures are all factors that threaten the viability of traditional agriculture and pastoralism now and for the future. The 'meltdown' narrative explains this situation very well, but as these contemporary cases show, socio-economic factors from growing population to market forces and national water policies are also critical factors of change. Society should find ways to ameliorate the adverse impacts of both climate and socio-economic pressures in order to secure their continued survival and adaptation.

\section{Discussion}

Does climate change mean the demise of rural communities in the Andes dependent on mountain sources of water for their agriculture and livelihoods? Comparison of the vulnerabilities of different localities over space and time in the Andes is a useful exercise to understand better the meaning and possible trajectories of the uncertain changes that are unfolding today due to anthropogenic climate change. Although this paper argues for a recasting of the melt-down narrative, with a large part of the focus on correctly portraying the heterogeneity of environmental change in the Andes, the construction of Andean peoples themselves too is in need of modification. Andean 'peasants' or 'small-scale farmers' or 'indigenous peoples' are discussed in the literature on the human dimensions of climate change impacts. They are the most vulnerable because they are poor (Smit and Wandel, 2006), and are dependent on agriculture (Lobell et al., 2008), rely on unmediated environmental resources (Smit \& Wandel 2006 in (Hallegatte et al., 2011)), yet they are the most in-balance, 'sustainable' actors in the landscape (Perez et al., 2010).

As is evident from the cases, the Andes are very diverse climatically and environmentally. In the highlands of Ecuador, the climate is relatively moist, although seasonal. Therefore rainfall, in addition to glacier and snow-melt is important for the present hydrological regime. Water stress here may develop where snow and ice-melt is not buffering streamflow during periods of drought. This is a similar situation for the Callejon de Huaylas in Peru. However, drought is endemic in Diaguitas, Chile, where rainfall most years is negligent, except during ENSO episodes. Meteorological drought, thus does not really affect agriculture in arid regions, however this is detrimental to pastoralism, as Young et al. (2010) reveal. But a hydrological drought, where river runoff falls sharply, as when glaciers and snow disappear in the headwaters of the Elqui Valley, presents a much more significant problem. Irrigated agriculture is very sensitive to changes in water abundance, so an increase in cultivated area due to accelerated snow and ice-melt is very vulnerable to diminished flows, already projected for the future of the Elqui Valley (ibid). Although glacier retreat is a very serious problem, as identified by the 'meltdown' narrative, the dynamic impacts of this varies across the Andes region. This is important to consider for the construction of adaptation measures tailored to specific locations.

Moreover, as is revealed by the comparison between past and contemporary societies, climate changes occur within a socio-historical as well as an environmental-historical context. For instance, the ecological collapse theory of Wari and Tiwanaku societies was revealed to be inconsistent with records of drought in the altiplano region of Peru and Bolivia (Williams 2002). Social vulnerabilities in this context, such as conflict and political 
problems, prove to be more convincing causal factors for their collapse. For this reason, it is important to consider factors of poverty, social-marginalization, centrality vs. peripherality, and power, all of which impact access and control of vital resources such as water. The actors competing for water in a watershed all have different degrees of access based on the fact that power and rights are also differential. The individual in Diaguitas has little chance at competing with large agri-business, due to the fact that Chilean policy favors market-driven agricultural growth. Therefore, the individual has less access to water in this context. As snow and ice-melt stress hydropower and urban interests in the Callejón de Huaylas, conflict with poor indigenous and rural communities over water allocation looms. Thus, there is much more than just climate changing the amount of water that is in a river or canal. "Water flows uphill to money", as the modern dictum states. Thus the question of adaptation is "for who's development, interests and benefit"? Adaptation of local, land-based irrigators in the Andes implies not only ecological adaptation to a changing water regime, but a struggle for their right to continue using water that is also fundamental to the adaptation of neo-liberal markets and mushrooming urban populations.

These aspects of vulnerability — environmental and social—are antipodes of two competing characterizations of the 'meltdown' narrative in the Andes. I argue that the construction of the meltdown narrative is approached from primarily a human-ecological tradition. Through this perspective, Andean livelihoods and production are characterized as the result of a particular environmental setting. When the snow and ice melts in this conceptualization of humans and environment, people are the victims that will inevitably disappear. The agency of the actors is lost in this almost environmentally-determinist version of the narrative. The timelessness of humans as 'adapted' to their environments neglects histories of social development, struggle and upheaval that are also part and parcel of the story of human adaptability. Thus, a political ecology of water in the Andes places the actor in a much more dynamic social role. Social organization and struggle are parts of the environmental story, and thus also of that of adaptation to climate change and melting glaciers and snow in the high mountains.

Thus, the comparison of the cases presented above emphasizes that the narrative of how melting snow and ice in the mountains due to climate change affects land-based peoples needs to ask more creatively how change will occur. Moreover, the different mechanisms of change-both social and environmental-need to be clarified in order to assess a society's chances for adaptation. The need for more complex, nuanced narratives of change in the Andes begs for the development of an 'ecology of change'.

A long-term historical perspective in the Andes shows that pre-Columbian to post-modern societies in Andes are irrigating as a method of livelihood. But what are the limits of this livelihood option? In many parts of the Andes, there are multiple sources and methods for appropriating water beyond just from snow and ice melt. This begs the re-crafting of the end-point of adaptation to hydrological change in the Andes.

Thus, the multiple environments of the Andes and the human communities inhabiting them, as well as the importance of historical context to these settings are incredibly diverse. The comparison of the vulnerabilities of past and present societies in the Andes (see Table 1) can help to place vulnerability in historical time. This helps to distinguish between types of impacts or hazards as singular events or constitutive of more long-term trends. 
Furthermore, the comparison of different localities through the Andes reveals the distinct nature of how environmental and social risk factors combine in specific places. For instance, in the arid environment of Diaguitas, Chile, the meaning of drought is much different-and more extreme-than in the relatively moist region of Cotacachi, Ecuador. By the same token, the disappearance of snow and ice in the high mountains of Ecuador will affect local agricultural systems much differently than in arid Chile, Peru or Bolivia. Thus it is important to acknowledge the diversity of hydrological conditions in the Andes, which therefore will have different impacts on the dynamics of human-natural systems in each location.

In sum, the vulnerabilities of past and contemporary Andean societies, presented in Table 1, reveal emerging vectors of vulnerability due to climate change, but also important, unexpected factors contributing to broader social vulnerability. These include the socioeconomic stressors and sensitivities of the Andean communities presented, but also some other factors such as vegetation change which typically aren't considered in the 'meltdown' narrative of climate change in the region. The implications of the comparison of past vs. contemporary societies, as well the juxtaposition of the groups within these, helps to broaden our understanding of the significance of global change across the Andes region. Once again, there is a greater complexity that emerges than the 'meltdown' narrative alone allows.

\section{Conclusions}

The cultures and environments of the Andes are far from homogenous, displaying vast array of different peoples in everything from tropical to polar climates. Knowledge of vulnerability and adaptation on the local level is a good starting point for understanding the heterogeneous nature of climate change and society while rectifying the impacts-dominated discourse in the Andes. Modeling projections of climate change is helpful for understanding potential trajectories of change, but should ask more creatively how change will occur. Will less glaciers and snow mean the end of Andean civilization? More knowledge on more complex trajectories of change is needed in order to cast an 'ecology of change'. The long-term socio-environmental perspective in the Andes shows that from pre-Columbian to contemporary societies in the Andes, irrigation is the basis of agricultural livelihood in the region. Climate change helps us ask what the limits of this livelihood option are. In many parts of the Andes, there are multiple ways of accessing and appropriating water for this (i.e. irrigation, groundwater pumping, 'galerías filtrantes', albarradas, etc. (see Jacobsen and McNeish, 2006). In addition to these, we can ask what solutions are available regionally and globally. Rhoads (2008)says "traditional knowledge is not enough". Today, we are least limited by information, and that is an important point, as the dictum 'knowledge is power' reminds. Knowledge is also possibility. With a more creative approach to framing the problem, we can hope to break out of stagnant narratives, and recast local realities with the help of local communities (i.e. Valdivia et al. 2010) to help imagine the myriad options for increasing adaptive capacity.

Future research should aim for comprehensive study of societal adaptation in the Andes, comparing past and future cases, also across world regions sharing similar challenges. Knowledge is power, but for successful adaptation, we should also be sharply aware of the flow of power that accompanies knowledge. 
Table 1: Past and Contemporary Andean Vulnerabilities

\begin{tabular}{|c|c|c|}
\hline $\begin{array}{l}\text { Climatic/ } \\
\text { Environmental } \\
\text { Exposure } \\
\text { Sensitivities }\end{array}$ & Past Societies & Comtemporary Societies \\
\hline Multi-YearDrought & $\begin{array}{l}\text { - Tiwanaku affected by general drought } \\
\text { (Williams 2002) } \\
\text { - Wari affected by general drought } \\
\text { (Williams 2002) }\end{array}$ & $\begin{array}{l}\text { - Diaguitas community, Elqui Valley, Chile sensitive to } \\
\text { decreasing river flow for irrigation due to melting snow/ice } \\
\text { in mountains in long-term; prolonged drought due to } \\
\text { intensification of ENSO (Young et al. 2010) }\end{array}$ \\
\hline $\begin{array}{l}\text { Seasonal Drought } \\
\text { (decrease in summer } \\
\text { runoff due to } \\
\text { glacier/snow loss) }\end{array}$ & & $\begin{array}{l}\text { - Natives of Cotacachi Volcano region, Ecuador experiencing } \\
\text { decreased flow from streams \& springs (Rhoades 2008) } \\
\text { - Quechua in Cordillera Blanca (Mark et al. 2010) } \\
\text { - Quechua in Cordillera Blanca (Bury et al. 2010) } \\
\text { - Aymarapeoples of Bolivian altiplano (Valdivia et al. 2010) } \\
\text { - Diaguitas community, Elqui Valley, Chile sensitive to } \\
\text { summer shortages of potable water (Young et al. 2010) }\end{array}$ \\
\hline Flooding & $\begin{array}{l}\text { - Tiwanaku\&Wari peoples affected, } \\
\text { possibly by ENSO related events, but } \\
\text { able to recover easily from local } \\
\text { impacts (Williams 2002) }\end{array}$ & $\begin{array}{l}\text { - Aymarapeoples of Bolivian altiplano (Valdivia et al. 2010) } \\
\text { - Diaguitas community, Elqui Valley, Chile, due to } \\
\text { intensification of ENSO cycle (Young et al. 2010) }\end{array}$ \\
\hline $\begin{array}{l}\text { DebrisFlow/ } \\
\text { Landslides }\end{array}$ & & $\begin{array}{l}\text { - Diaguitas community, Elqui Valley, Chile due to ENSO } \\
\text { (Young et al. 2010) }\end{array}$ \\
\hline $\begin{array}{l}\text { ChangingWeatherPa } \\
\text { tterns/ Climate }\end{array}$ & & $\begin{array}{l}\text { - Natives of Cotacachi Volcano region, Ecuador (Rhoades } \\
\text { 2008) } \\
\text { - Quechua in Cordillera Blanca affected by impacts on crops, } \\
\text { livestock (Mark et al. 2010) } \\
\text { - Aymara peoples of Bolivian altiplano affected by later onset } \\
\text { of rains (Valdivia et al. 2010) }\end{array}$ \\
\hline $\begin{array}{l}\text { Extreme Weather/ } \\
\text { Precipitation/ } \\
\text { Freezing Events }\end{array}$ & & $\begin{array}{l}\text { - Natives of Cotacachi Volcano region, Ecuador perceived } \\
\text { higher winds (Rhoades 2008) } \\
\text { - Quechua in Cordillera Blanca affected by impacts on crops, } \\
\text { livestock, human health (Mark et al. 2010) } \\
\text { - Quechua in Cordillera Blanca (Bury et al. 2010) } \\
\text { - Aymarapeoples of Bolivian altiplano (Valdivia et al. 2010) }\end{array}$ \\
\hline $\begin{array}{l}\text { Receding Glaciers/ } \\
\text { Snow-line due to } \\
\text { Warming }\end{array}$ & & $\begin{array}{l}\text { - Natives of Cotacachi Volcano region, Ecuador potentially } \\
\text { affected by decrease in tourism (Rhoades 2008) } \\
\text { - Quechua in Cordillera Blanca affected by decreasing } \\
\text { tourism (Mark et al. 2010) } \\
\text { - Quechua in Cordillera Blanca affected by decreasing } \\
\text { tourism (Bury et al. 2010) }\end{array}$ \\
\hline Pests & & $\begin{array}{l}\text { - Aymara peoples' of Bolivian altiplano agriculture affected } \\
\text { (Valdivia et al. 2010) }\end{array}$ \\
\hline $\begin{array}{ll}\text { Potable } & \text { Water } \\
\text { Shortages } & \end{array}$ & & $\begin{array}{l}\text { - Diaguitas community, Elqui Valley, Chile due to summer } \\
\text { shortages, increased demand from industry \& tourism } \\
\text { (Young et al. 2010) }\end{array}$ \\
\hline Vegetation Changes & & $\begin{array}{l}\text { - Diaguitas community, Elqui Valley, Chile, goat herding } \\
\text { affected by drought (Young et al. 2010) }\end{array}$ \\
\hline
\end{tabular}




\begin{tabular}{|c|c|c|}
\hline $\begin{array}{l}\text { Socio-economic } \\
\text { Exposure } \\
\text { Sensitivities } \\
\end{array}$ & Past Societies & Comtemporary Societies \\
\hline $\begin{array}{lr}\text { Resource } & \text { (Mis-) } \\
\text { Management } & \text { (i.e. } \\
\text { water) } & \\
\end{array}$ & - Tiwanaku (Williams 2002) & \\
\hline $\begin{array}{l}\text { SocialConflict/ } \\
\text { Unrest }\end{array}$ & $\begin{array}{l}\text { - Tiwanaku political unrest (Williams } \\
\text { 2002) } \\
\text { - Inca due to Spanish Conquest } \\
\text { (Chepstow-Lusty 2009) }\end{array}$ & \\
\hline $\begin{array}{lr}\text { Loss of Neighboring } \\
\text { Polity/ } & \text { Trade } \\
\text { Partner } & \\
\end{array}$ & - Wari (Williams 2002) & \\
\hline $\begin{array}{l}\text { Variable Access to } \\
\text { Water Resources }\end{array}$ & & $\begin{array}{l}\text { - Natives of CotacachiVolcanoregion, Ecuador (Rhoades } \\
\text { 2008) } \\
\text { - Quechua in Cordillera Blanca (Bury et al. 2010) }\end{array}$ \\
\hline LowLivestock Prices & & - Aymarapeoples of Bolivian altiplano (Valdivia et al. 2010) \\
\hline $\begin{array}{l}\text { Adult } \\
\text { Unemployment }\end{array}$ & & $\begin{array}{l}\text { - Aymarapeoples of Bolivian altiplano (Valdivia et al. 2010) } \\
\text { - Diaguitas community, Elqui Valley, Chile reduced income } \\
\text { diversity leading to seasonal migration (Young et al. 2010) }\end{array}$ \\
\hline $\begin{array}{l}\text { International } \\
\text { Demand }\end{array}$ & & $\begin{array}{l}\text { - Diaguitas community, Elqui Valley, Chile due to agri- } \\
\text { business response to international fruit \& wine demand } \\
\text { (Young et al. 2010) }\end{array}$ \\
\hline $\begin{array}{l}\text { National } \\
\text { EconomicStrategies }\end{array}$ & & $\begin{array}{l}\text { - Diaguitas community, Elqui Valley, Chile affected by } \\
\text { export-oriented policy in national water law (Young et al. } \\
2010 \text { ) } \\
\text { - Private investment in water use elevated to 'juridical } \\
\text { principle' in } 2009 \text { Peruvian Law of Hydraulic Resources } \\
\text { (Borg-Rasmussen 2010) }\end{array}$ \\
\hline
\end{tabular}

\section{References}

Hallegatte, S., Przyluski, V. \& Vogt-Schilb, A. (2011): Building world narratives for climate change impact, adaptation and vulnerability analyses. Nature Climate Change, 1, 151-155.

Jacobsen, F. F. \& Mcneish, J.A. (eds.) (2006): From Where Life Flows: The Local Knowledge and Politics of Water in the Andes, Trondheim: Tapir Academic Press.

Kaser, G. (1999): A review of the modern fluctuations of tropical glaciers. Global and Planetary Change, 22, 93-103.

Lamadrid, A. (2008): High Mountain Melt-Down: Local Perceptions of Global Warming in the Andes and Himalayas. Master's thesis. Universitetet i Bergen, Norway.

Lobell, D. B., Burke, M. B., Tebaldi, C., Mastrandrea, M. D., Falcon, W. P. \& Naylor, R. L. (2008): Prioritizing Climate Change Adaptation Needs for Food Security in 2030. Science, 319, 607-610.

Mark, B. G., Bury, J., Mckenzie, J. M., French, A. \& Baraer, M. (2010): Climate Change and Tropical Andean Glacier Recession: Evaluating Hydrologic Changes and Livelihood Vulnerability in the Cordillera Blanca, Peru. . Annals of the Association of American Geographers, Special Edition on Climate Change, 100.

Mark, B. G., Mckenzie, J. M. \& Gómez, J. (2005): Hydrochemical evaluation of changing glacier meltwater contribution to stream discharge: Callejon de Huaylas, Peru / Evaluation 
hydrochimique de la contribution évolutive de la fonte glaciaire à l'écoulement fluvial: Callejon de Huaylas, Pérou. Hydrological Sciences Journal, 50, 987.

Mark, B. G. \& Seltzer, G. O. (2003): Tropical glacier meltwater contribution to stream discharge: a case study in the Cordillera Blanca, Peru. Journal of Glaciology, 49, 271-281.

Perez, C., Nicklin, C., Dangles, O., Vanek, S., Sherwood, S., Halloy, S., Garrett, K. \& Forbes, G. (2010): Climate change in the High Andes: Implications and adaptation strategies for small-scale farmers. International Journal of Environmental, Cultural, Economic and Social Sustainability, 6.

Rhoades, R. (2008): Disappearance of the glacier on mama cotacachi: Ethnoecological research and climate change in the Ecuadorian Andes. Pirineos, 37-50.

Smit, B. \& Wandel, J. (2006): Adaptation, adaptive capacity and vulnerability. Global Environmental Change, 16, 282-292.

Vuille, M., Francou, B., Wagnon, P., Juen, I., Kaser, G., Mark, B. G. \& Bradley, R. S. (2008): Climate change and tropical Andean glaciers: Past, present and future. Earth-Science Reviens, 89, 79-96. 